\title{
Description of Four New Species of Genus Acanthaegilips Ashmead, 1897 (Hymenoptera: Figitidae: Anacharitinae) from Colombia
}

\author{
N Mata-Casanova ${ }^{1}$, J Selfa ${ }^{2}$, J Pujade-Villar ${ }^{1}$ \\ ${ }^{1}$ Depto de Biologia Animal, Facultat de Biologia, Univ de Barcelona, Barcelona, Spain \\ ${ }^{2}$ Depto de Zoologia, Facultat de Ciències Biològiques, Campus de Burjassot-Paterna, Univ de València, Burjassot, València, Spain
}

\section{Keywords}

Acanthaegilips, Colombia, new species, revision

\section{Correspondence}

N. Mata-Casanova, Depto de Biologia Animal, Facultat de Biologia, Univ de Barcelona, Avda. Diagonal 645, 08028 Barcelona, Spain; feofitotu@gmail.com

Edited by Ranyse B Querino - Embrapa

Received 1 February 2016 and accepted 8 February 2017

Published online: 27 March 2017

(C) Sociedade Entomológica do Brasil 2017

\section{Introduction}

Anacharitinae is one of the 11 subfamilies of microcynipoid wasps included in Figitidae (Paretas-Martínez et al 2011). They can be easily distinguished from other figitids by the presence of three characters (Ros-Farré et al 2000): (1) rounded and continuous pronotal plate, (2) mandibles broadly overlapping and (3) triangular-shaped head in anterior view. The subfamily currently includes nine described genera (MataCasanova \& Pujade-Villar 2013a): Acanthaegilips Ashmead, 1897; Acanthaegilopsis Pujade-Villar, 2013; Aegilips Haliday, 1835; Anacharis Dalman, 1823; Calofigites Kieffer, 1909; Hexacharis Kieffer, 1907; Proanacharis Kovalev, 1996; Solenofigites Díaz 1979 and Xyalaspis Hartig, 1843.

Acanthegilips is one of the three Anacharitinae endemic to the Neotropical region, along with Calofigites and Solenofigites. Species of Acanthaegilips have an oblique groove on the mesopleuron similar to Solenofigites; however, Acanthaegilips can be distinguished from Solenofigites by having an elongated scutellar spine, large scutellar foveae and modified male flagellomeres (in some species); all of these characteristics are absent in Solenofigites. The
Anacharitinae are known to attack the aphid-feeding larvae of Hemerobiidae (Díaz 1979; New 1979; Kierych 1984; Fergusson 1985; Miller \& Lambdin 1985; Cave \& Miller 1987); Acanthaegilips is no exception, and it has been recorded from the cocoons of the hemerobiid Notiobiella cixiiformis (Gerstaecker, 1888) (Mata-Casanova et al 2014).

Prior to this work, Acanthaegilips included 16 species (Mata-Casanova et al 2014), mostly concentrated in Northern South America. Venezuela had the highest record of Acanthaegilips species, with nine recorded species there (Ros-Farré et al 2003; Pujade-Villar et al 2009a; Pujade-Villar et al 2009b; Restrepo-Ortiz et al 2010; Mata-Casanova et al 2014), with Colombia a close second with seven species (Restrepo-Ortiz et al 2010; Mata-Casanova \& Pujade-Villar $2013 \mathrm{~b})$. In the present work, four new species of Acanthaegilips from Colombia are described: $A$. boyacensis Mata-Casanova \& Pujade-Villar sp. n., A. curvis MataCasanova \& Pujade-Villar sp. n., A. timidus Mata-Casanova \& Pujade-Villar sp. n. and A. truncatus Mata-Casanova \& PujadeVillar sp. n. Their morphological features and affinities with other Acanthaegilips species are discussed. Considering that the last key of genus Acanthaegilips is the one found in Ros- 
Farré et al (2003), an updated key on the genus has been included, taking into account the species described since then and the interesting morphological features they present.

\section{Material and Methods}

The material examined was collected in the period 2000-2004 with Malaise traps as part of the project "Biodiversidad Insectos de Colombia", carried out by the Instituto Alexander von Humboldt (IAvH; Villa de Leiva, Colombia), the University of Kentucky (UK; Lexington, USA) and the Natural History Museum of Los Angeles (NHM; Los Angeles, USA). It is deposited in lavH and the Universitat de Barcelona (UB, Barcelona, Spain). Fourteen undetermined specimens have been studied: eight females and six males.

Morphological terms used are those of Richards (1977) and Ronquist (1995). For the determination of specimens, we used the keys of Ros-Farré et al (2003). All measurements are relative except for the body length. Measurements and abbreviations include F1-F12, first and subsequent flagellomeres; post-ocellar distance $(\mathrm{POL})$ is the distance between the inner margins of the posterior ocelli; ocular-ocellar distance (OOL) is the shortest distance between the inner margin of the compound eye and the outer edge of the posterior ocellus and lateral-frontal ocellar distance (LOL) is the distance between the edges of the lateral and frontal ocelli. Antennal formula includes scape, pedicel and flagellomere length and relative width in brackets.

The SEM images included were made in 'Serveis Científico-Tècnics' of the University of Barcelona. The fieldemission gun environmental scanning electron microscope (FEl Quanta 200 ESEM) was used for high-resolution imaging, under a low voltage $(12.0 \mathrm{kV})$ and without gold-coating of the specimens in order to preserve the material.

\section{Results}

\section{Key to the species of Acanthaegilips Ashmead, 1897}

1. Mesoscutum smooth; notauli tenuous and incomplete

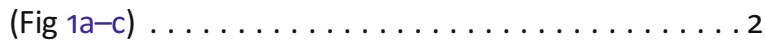

- Mesoscutum carinate or areolate; notauli complete, although in some specimens are hard to distinguish from the heavily areolate sculpture (Figs $1 \mathrm{~d}-\mathrm{h}$ and 2 ). ....4

2. Scutellum shorter than mesoscutum in dorsal view (Fig 1a).

A. timidus Mata-Casanova \& Pujade-Villar sp. $\mathrm{n}$

- $\quad$ Scutellum longer than mesoscutum in dorsal view (Fig 1b, c).

3. Radial cell closed; post-ocular furrow absent; malar furrow slightly curved (Fig 3e) (only male known).
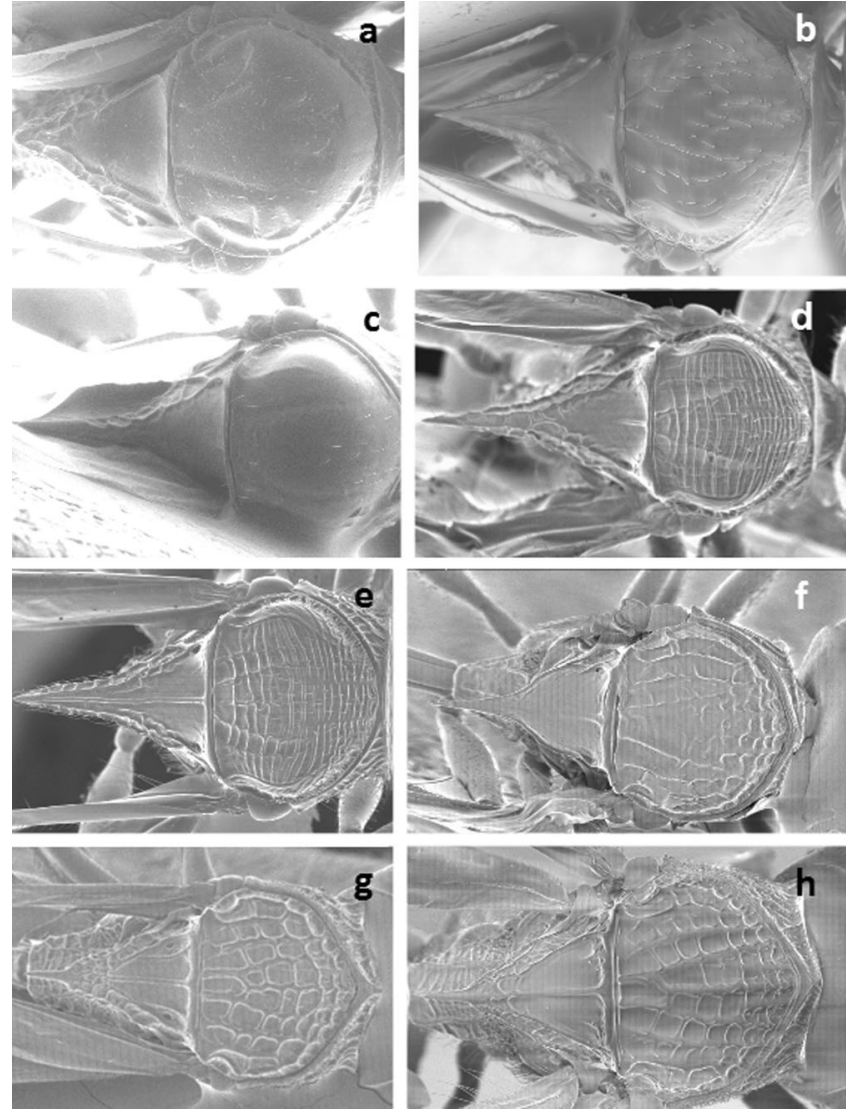

Fig. 1 Mesosoma in dorsal view of $A$. timidus sp. n. (a), A. boyacensis sp. n. (b), A. curvis sp. n. (c), A. colombiensis (d), A. venezuelensis (e), A. alienus (f), A. dentis (g) and $A$. carinatus (h).

..... A. boyacensis Mata-Casanova \& Pujade-Villar sp. $\mathrm{n}$

- Radial cell open, post-ocular furrow present; malar furrow strongly curved and reaching the post-ocular furrow (Fig 3f) (only female known).

............. A. curvis Mata-Casanova \& Pujade-Villar sp. $\mathrm{n}$

4. Mesoscutum transversely carinated (Fig 1d, e)..............5

- Mesoscutum areolate (Figs $1 f-h$ and 2)............................6

5. Malar furrow strongly curved (Fig 3f); median mesoscutal impression not divided (Fig 1d).

.... A. colombiensis Pujade-Villar \& Restrepo-Ortiz, 2010

- Malar furrow slightly curved (Fig 3e), median mesoscutal impression internally divided into two cells (Fig 1e).........

A. venezuelensis Ros-Farré \& García, 2010

6. Scutellum concave, strongly inclined on each side of the median scutellar carina; male flagellomeres never modified, propodeum with three longitudinal ridges without any sculpture between; notauli not formed by a row of cells.

A. alienus Ros-Farré \& Pujade-Villar, 2003

- Scutellum flat; male antennae with some flagellomeres from $F 1$ to $F 6$ dorsolaterally expanded (Fig $3 \mathrm{i}, \mathrm{j}$ ); propodeum areolate, notauli consisting in a row of cells. 


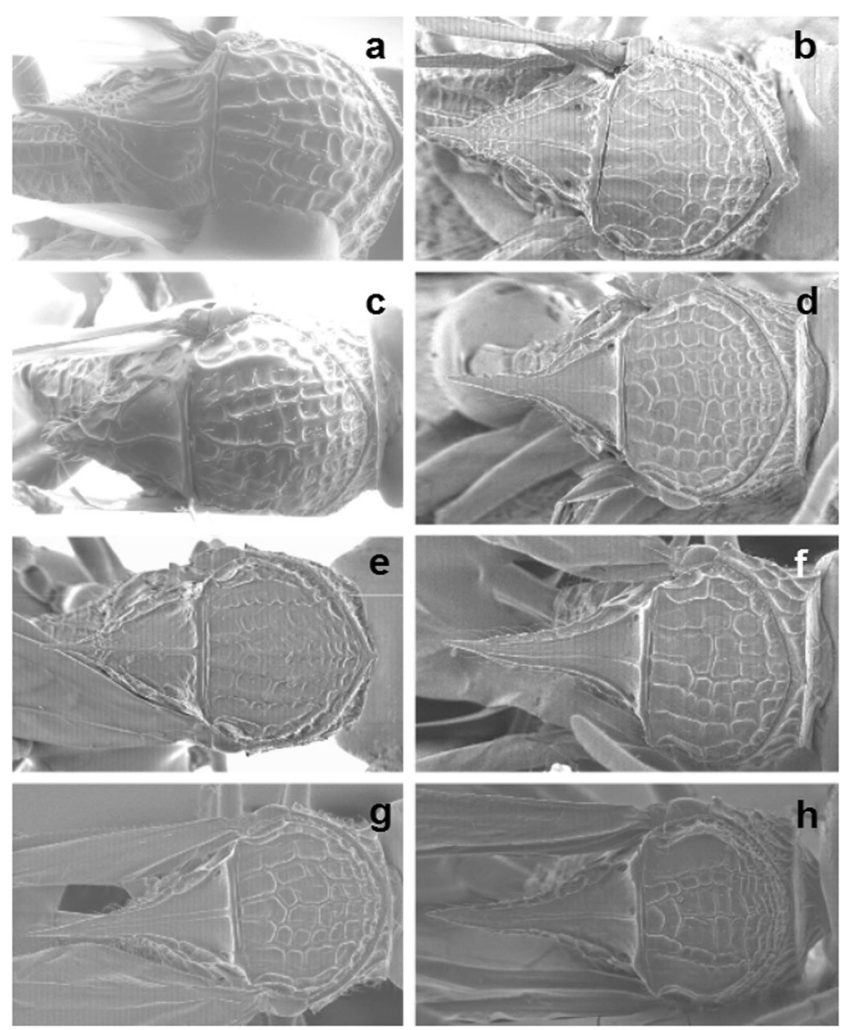

Fig. 2 Mesosoma in dorsal view of A. notiobiellus (a), A.occultus (b), A. truncatus sp. n. (c), A. huggerti (d), A. exiguus (e), A. braziliensis (f), $A$. levis (g) and A. palmirae (h).

7. Radial cell open. .8

- Radial cell closed........................................................17

8. Malar furrow straight to slightly curved, usually connected with post-ocular furrow (Fig 3g).

- Malar furrow strongly curved, post-ocular furrow absent (Fig 3e).

9. Scutellar foveae with an internal longitudinal carina (foveal carina) dividing them into two areas each (Figs $19, \mathrm{~h}$ and $2 \mathrm{a}, \mathrm{b})$; pronotal plate produced into a sharp and strongly raised dorsal tooth in lateral view (Fig 4a-d); petiole as wide as long, sometimes slightly wider than long. ...10

- Scutellar foveae without any internal longitudinal carina dividing them (Figs $2 c-h$ and $3 a-d)$; pronotal plate with a small and short dorsal tooth in lateral view (Figs $4 \mathrm{e}, \mathrm{f}$ and $5 \mathrm{a}-\mathrm{d}$ ); petiole 1.5 to 2 times wider than long. ....13

10. Malar and post-ocular furrows strongly impressed (Fig 4a); foveal carina reaching the posterolateral margin of the scutellar foveae (Fig 1g) (only female known). .................... A. dentis Ros-Farré \& Pujade-Villar, 2003

- $\quad$ Malar furrow effaced; post-ocular furrow weak but with a line of hairs running below the post-ocular and malar furrows; foveal carinae less evident and not reaching the posterolateral margin of the scutellar foveae.
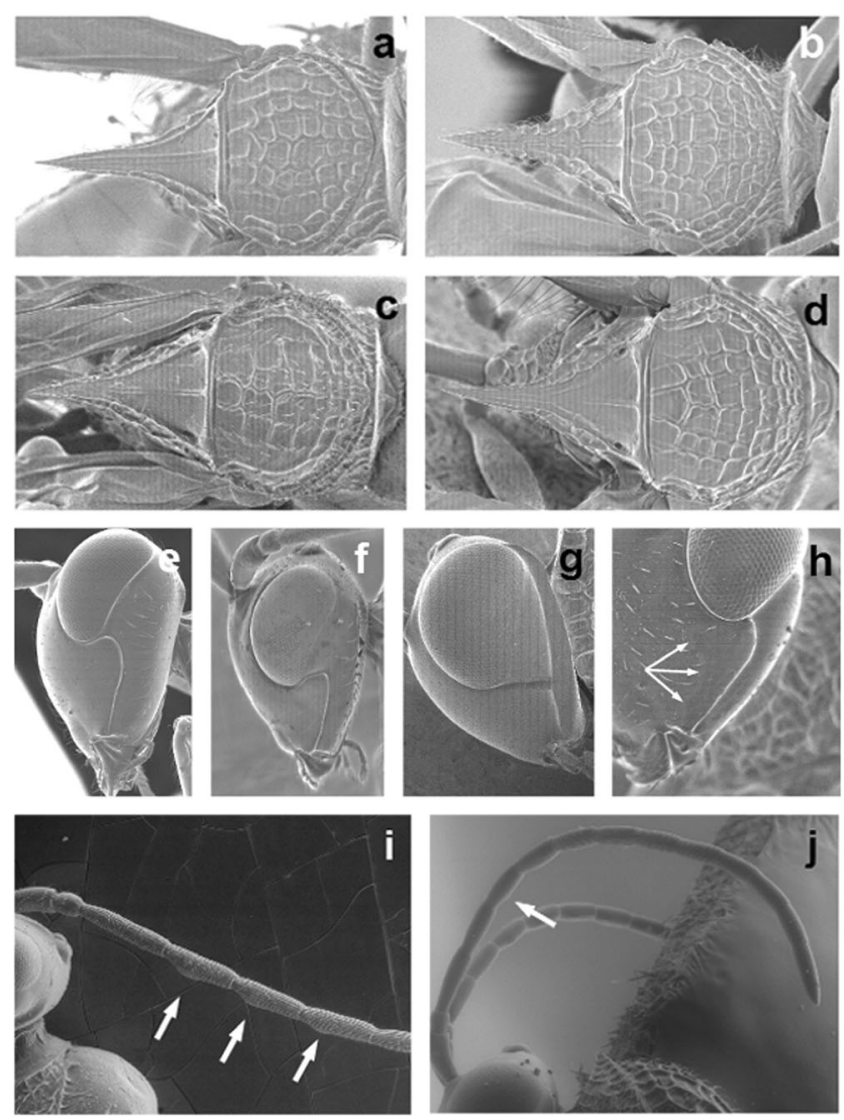

Fig 3 Mesosoma in dorsal view of $A$. masneri (a), A.macropennis (b), $A$. diazae (c) and $A$. ashmeadi (d). Detail of malar area of $A$. venezuelensis (e), A. colombiensis (f), A. dentis (g) and A. palmirae (h). Detail of male flagellomeres of $A$. timidus (i) and $A$. notobiellus (j).

11. Lateral surface of pronotum with coarse transverse carina in ventral part and with areolate sculpture in dorsal part (Fig 4b). ........A. carinatus Ros-Farré \& Pujade-Villar, 2003

- $\quad$ Lateral surface of pronotum completely areolate; lateral pits of scutellar fovea presents.

....12

12. Median mesoscutal furrow $1 / 4$ to $1 / 3$ of mesoscutum length; two or three foveal carinae present (Fig 2a); lateral pits of scutellum absent; scutellar spine curved downwards.

..A. notobiellus Mata-Casanova \& Pujade-Villar, 2014

- Median mesoscutal furrow $1 / 4$ or less than mesoscutum length, one foveal carina present (Fig 2b), lateral pits of scutellum present; scutellar spine straight in lateral view.

A. occultus Ros-Farré \& Pujade-Villar, 2003

13. Scutellum shorter than mesoscutum in dorsal view (Fig 2c); scutellar spine blunt-ended (Fig 4e)..

A. truncatus Mata-Casanova \& Pujade-Villar sp. $\mathrm{n}$

- Scutellum as long as mesoscutum in dorsal view, sometimes longer; scutellar spine spike-ended.

. .14

14. Scutellar disc narrows abruptly posteriorly and the scutellar spine is entirely slender (Fig 2d); scutellar spine straight in lateral view; lateral pit of scutellar fovea deep. .............. A. huggerti Sporrong \& Ros-Farré, 2003 

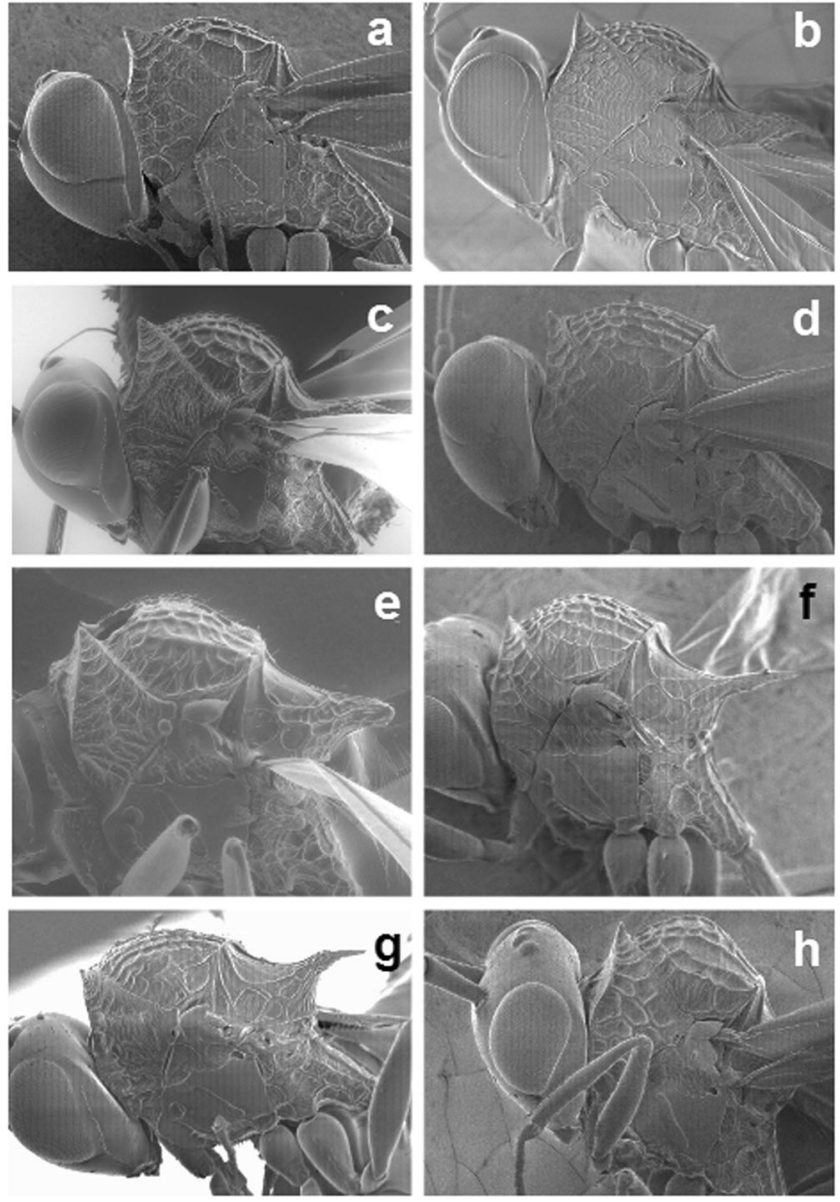

Fig 4 Mesosoma in lateral view of $A$. dentis (a), $A$. carinatus (b), $A$. notiobiellus (c), A.occultus (d), A. truncatus sp. n. (e), A. huggerti (f), A. exiguus (g) and A. braziliensis (h).

- $\quad$ Scutellar spine narrowing abruptly before apex (Fig 2e); scutellar spine curved downwards in lateral view; lateral pit of fovea superficial and indistinct (only male known)

A. exiguus Ros-Farré \& Pujade-Villar, 2003

15. Scutellar carina visible, in lateral view, running from pronotum to median sulcus; scutum in profile with a distinct hump; pronotal plate with a pointed dorsal tooth when viewed laterally (Fig $4 \mathrm{~h}$ ).

A. braziliensis Ashmead, 1896

- Scutellar carina absent; scutum curved in profile but not humped; pronotal plate dorsally raised but not ending in a pointed dorsal tooth when examined laterally. .16

16. Mesoscutum completely areolate (Fig 2g); malar area smooth (only female known).

A. levis Ros-Farré \& Pujade-Villar, 2003

- Mesoscutum surface between notauli and parapsidal signum smooth (Fig 2h); coriaceous line present anterior in front of malar furrow (Fig $3 \mathrm{~h}$ ) (only female known).

..A. palmirae Mata-Casanova \& Pujade-Villar, 2013

17. Pronotal plate ending dorsally in a small tooth; petiole laterally costate (Fig 5a) (only female known).

A. masneri Sporrong \& Ros-Farré, 2003

- Pronotal plate rounded dorsally; petiole laterally entirely smooth or slightly carinate anteriorly......

...18

18. Scutellar foveae smooth anteriorly; reticulate posteriorly (Fig 3b) (more clear on females), male placodeal sensilla present and abundant from $\mathrm{F} 1$ to the end of the antenna.

A. macropennis Sporrong \& Ros-Farré, 2003

- Scutellar foveae entirely smooth; male placodeal sensilla dorsally absent on F1 and dorsally scarce or absent on at least some of the following flagellomeres.

19. Notauli complete; mesoscutum with weak areolate sculpture, smooth between parapsidal signum and parascutal impression; parapsidal signum strongly raised and conspicuous (Fig $3 \mathrm{C}$ ); male placodeal sensilla present on $F_{1}$, dorsally absent from $F_{1}$ to $F_{5}$ and sparse from $\mathrm{F} 6$ to $\mathrm{F} 7$ (only male known).

A. diazae Ros-Farré \& Pujade-Villar, 2003 Notauli incomplete or not even present, reaching $1 / 2$ the length of mesoscutum; mesoscutum coarsely areolate; parapsidal signum quite conspicuous and not raised (Fig 3d); male placodeal sensilla dorsally absent on $\mathrm{F} 1$ and $\mathrm{F} 2$, sometimes also on $\mathrm{F} 3$; and very scarce on F4............A. ashmeadi Ros-Farré \& Pujade-Villar, 2003

\section{Acanthaegilips boyacensis sp.n. Mata-Casanova \&} Pujade-Villar

Diagnosis. Species belonging to Acanthaegilips with a smooth mesoscutum. Acanthaegilips boyacensis $\mathrm{n}$. $\mathrm{sp}$. is very similar to $A$. curvis $n$. sp., but it presents a closed radial cell, a slightly curved malar furrow and lacks a post-ocular furrow (in A. curvis n. sp., radial cell open, malar furrow strongly curved and connected to a clearly distinguishable postocular furrow).

\section{Description. (Only male known)}

Length. Body $2.8 \mathrm{~mm}$. Wing $2.9 \mathrm{~mm}$. Antenna $2.7 \mathrm{~mm}$.

Colour. Head, mesosoma and metasoma black. Antennae dark brown, scapus black and pedicel. Mandibles reddish brown with darker teeth. Legs brownish, coxae darker.

Head. Head glabrous; 1.2 times wider than high in anterior view and 2 times wider than long in dorsal view. Malar furrow slightly curved, post-ocular furrow absent (Fig 2e). Genal 

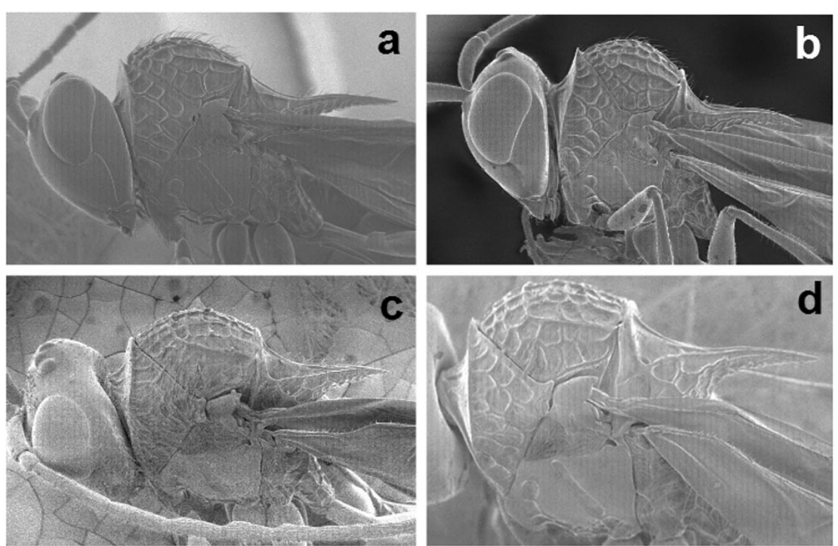

Fig. 5 Mesosoma in lateral view of $A$. masneri (a), A. macropennis (b), $A$. diazae (c) and A. ashmeadi (d).

carina absent, occipital carina strong. Malar space length 0.8 times that of compound eye height. Transfacial line 1.4 times longer than compound eye height. Diameter of toruli bigger than ocular-torular distance but shorter than intertoruli distance. Compound eyes glabrous. POL/OOL/LOL ratio is $7: 4.5: 2$ in males; ocelli diameter 2.5 .

Antennae. Flagellomeres cylindrical, glabrous. Male antennae with second to fourth flagellomeres not dorsolaterally expanded. Male antennal formula: 11(4), 3(3), 13(3), 10(3), 9(3), 9(3), 9(3), 8(3), 8(3), 8(3), 7.5(3), 7(3), 7(3), 9(3). Placodeal sensilla starting at F1 but not abundant until F4.

Mesosoma. Lateral pronotal carinae not dorsomedially projected to form raised tooth (Fig 2a). Pronotal plate smooth and glabrous. Pronotum smooth except for few tenuous transverse carinae, densely pubescent. Mesoscutum completely smooth (Fig 1C), 1.2 times wider than long in dorsal view. Median mesoscutal impression absent. Notauli tenuous, indistinct in anterior half of mesoscutum. Hair line on anterior and lateral margins of scutum absent. Parapsidal signum absent, tenuous sulcus present instead. Scutellum 1.1 times longer than mesoscutum in dorsal view. Interfoveal line absent, dorsal scutellum smooth with indistinguishable scutellar foveae (Fig 1c); scutellum laterally areolate. Lateral pits of scutellar foveae present next to scutellar margin. Scutellar spine short and pointed, not distinguished from scutellum, about $1 / 2$ of scutellar length. Scutellar disc in lateral view gradually descending towards terminus of spine. Mesopleural impression narrow, straight, without trace of internal carinae (Fig 2a). Mesopleural triangle smooth, densely pubescent. Propodeum areolate, lateral and median propodeal carinae present, transversely carinate in region between lateral carinae.
Wings. Pubescent. Radial cell of forewing closed, 3.1 times longer than wide. R1 complete. Marginal pubescence of wing denser at apical third.

Metasoma. Petiole as long as wide, slightly shorter than third coxa. Petiole dorsally smooth, latero-ventrally costate. Third abdominal tergum 1.1 times longer than fourth tergum in dorsal view. Fifth and sixth abdominal terga not visible from dorsal view.

Type Material. Holotype $\delta$ deposited in IAvH with the following labels: “Colombia, Boyacá, PNN Iguaque, El Boquerón, $5^{\circ} 25^{\prime} \mathrm{N} 73^{\circ} 27^{\prime} \mathrm{W}, 2600 \mathrm{~m}$, Malaise, 1-27.XII.2002: P. Reina leg" (white label); "Holotype $\hat{O}$ of $A$. boyacensis desig. MataCasanova" (red label).

Derivatio Nominis. The specific name makes reference to the Colombian province of Boyacá, the place where the only known specimen of the species was found.

\section{Biology. Unknown.}

Distribution. Neotropical. Only collected from Colombia.

\section{Acanthaegilips curvis sp.n. Mata-Casanova \& Pujade-Villar}

Diagnosis. This species has a smooth mesoscutum and tenuous notauli, characters not seen in other Acanthaegilips species except for $A$. boyacensis n. sp. and A. timidus n. sp. It has an elongate scutellum, a character that separates it from $A$. timidus $\mathrm{n}$. sp. (scutellum shorter than mesoscutum in $A$. timidus n. sp.). A. curvis can be separated from A. boyacensis $\mathrm{n}$. sp. by having an open radial cell and post-ocular furrow (radial cell closed and post-ocular furrow absent in $A$. boyacensis $\mathrm{n} . \mathrm{sp}$.).

\section{Description. (Only female known)}

Length. Body $2.5 \mathrm{~mm}$. Wing $2.8 \mathrm{~mm}$. Antenna $2.3 \mathrm{~mm}$.

Colour. Head, mesosoma and metasoma black. Antennae dark brown, scapus black and pedicel. Mandibles reddish brown with darker teeth. Legs brownish, coxae darker.

Head. Head glabrous; 1.1 times wider than high in anterior view, 2 times wider than long in dorsal view. Malar furrow strongly curved, connected with post-ocular furrow (Fig 2f). Genal carina absent, occipital carina strong. Malar space length 0.7 times that of compound eye height. Transfacial line 1.2 times longer than compound eye height. Diameter of toruli bigger than ocular-torular distance but shorter than intertoruli distance. Compound eyes glabrous. POL/OOL/LOL ratio is 7:5:3 in females; ocelli diameter 2 . 
Antennae. Flagellomeres cylindrical, glabrous. Female antennal formula: 10(3.5), 3(3), 10(2), 8(2), 8(2), 7.5(2), 7.5(2), 7(2), $7(2.5), 6(3), 6(3), 5(3), 9(3)$. Placodeal sensilla starting at F6 in females.

Mesosoma. Lateral pronotal carinae not dorsomedially projected to form raised tooth (Fig $2 \mathrm{~b}$ ). Pronotal plate smooth and glabrous. Pronotum smooth with some transverse carinae, presence of some scarce long hyaline hairs in upper pronotum. Mesoscutum completely smooth (Fig 1a), 1.3 times wider than long in dorsal view. Median mesoscutal impression absent. Notauli tenuous, indistinct in anterior half of mesoscutum. Hair line on anterior and lateral margins of scutum absent. Parapsidal signum very tenuous. Scutellum 1.2 times longer than mesoscutum in dorsal view. Interfoveal line absent, dorsal scutellum smooth with indistinguishable scutellar foveae (Fig 1a); scutellum laterally areolate. Lateral pits of scutellar foveae small, next to scutellar margins. Scutellar spine short, pointed, about $1 / 2$ of scutellar total length. Scutellar disc in lateral view gradually descending towards terminus of spine. Mesopleural impression narrow, straight, with weak internal carinae (Fig 2b). Mesopleural triangle smooth, sparsely pubescent. Propodeum areolate, lateral and median propodeal carinae present, transversely carinate between lateral carinae.

Wings. Pubescent. Radial cell of forewing open, three times longer than wide. R1 absent. Marginal pubescence of wing denser at apical third.

Metasoma. Petiole as long as wide, 0.7 times of third coxa length. Petiole dorsally smooth, latero-ventrally costate. Third abdominal tergum as long as fourth tergum in dorsal view. Fifth and sixth abdominal terga not visible from dorsal view.

Type Material. Holotype $q$ deposited in IAvH with the following labels: "Colombia, Cundinamarca, PNN Chingaza, Charrascales, $4^{\circ} 34^{\prime} \mathrm{N} 73^{\circ} 45^{\prime} \mathrm{W}, 2990 \mathrm{~m}$, Malaise, 424.IV.2002: F. Guzma". (white label); "Holotype $ᄋ$ of A. curvis desig. Mata-Casanova" (red label).

Derivatio Nominis. The specific name makes reference to the curved malar furrow, the key character that casts the species apart from the closely related $A$. boyacensis $\mathrm{n}$. sp.

Biology. Unknown.

Distribution. Neotropical. Only collected from Colombia.

Acanthaegilips timidus sp.n. Mata-Casanova \& Pujade-Villar

Diagnosis. This species has a smooth mesoscutum and short scutellar spine. The smooth mesoscutum is also present in
A. variabilis sp. n., but $A$. variabilis sp. n. presents a short scutellar spine and dorsolateral expanded second, third and fourth flagellomeres in males (scutellar spine longer than mesoscutum and no modified male flagellomeres in $A$. variabilis $\mathrm{sp} . \mathrm{n}$.).

Description. (Female)

Length. Body 2.1-2.5 mm. Wing 2.5-2.9 mm. Antenna 2.4$2.5 \mathrm{~mm}$.

Colour. Head, mesosoma and metasoma black. Antennae dark yellowish brown. Mandibles yellowish brown with darker teeth. Legs yellowish brown, coxae and femurs darker. Wing veins dark brown.

Head. Head glabrous; 1.1 times wider than high in anterior view, 2.1 times wider than long in dorsal view. Malar furrow apparent and slightly curved, connected with post-ocular furrow. Genal carina absent, occipital carina strong. Malar space length 0.6 times of compound eye height. Transfacial line as long as compound eye height. Diameter of toruli equal to ocular-torular distance but bigger than intertoruli distance. Compound eyes glabrous. POL/OOL/LOL ratio is 5:5:2; ocelli diameter 2 .

Antennae. Flagellomeres cylindrical, glabrous. Female antennal formula: 11(3), 3(3), 13(2), 11(2), 10(2), 10(2), 7.5(2), 7.5(2), $6(3), 6(3), 6(3), 5(3), 9(3)$. Placodeal sensilla starting at F5.

Mesosoma. Lateral pronotal carinae not dorsomedially projected to form raised tooth (Fig 2c). Pronotal plate smooth. Pronotum smooth, with some scarce transverse carinae; lower half alutaceous, upper half with sparse long hyaline hairs. Mesoscutum completely smooth (Fig 1d), 1.2 times wider than long in dorsal view. Median mesoscutal impression absent. Notauli tenuous, indistinct in anterior half of mesoscutum. Hair line on anterior and lateral margins of scutum absent. Parapsidal signum absent. Scutellum as long as mesoscutum in dorsal view. Interfoveal line absent, dorsal scutellum smooth with indistinguishable scutellar foveae (Fig 1d); scutellum laterally areolate. Laterals pit of scutellar foveae absent. Scutellar spine short and pointed but never distinguished from scutellum, about $1 / 3$ of scutellar length. Scutellar disc in lateral view gradually descending towards terminus of spine. Mesopleural impression narrow, straight, without traces of internal carinae (Fig 2c). Mesopleural triangle coarsely sculptured, glabrous. Propodeum coriaceous and areolate, presence of an irregular median carina.

Wings. Pubescent. Radial cell of forewing closed, 3.8 times longer than wide. R1 complete. Marginal pubescence of wing denser at apical third. 
Metasoma. Petiole as long as wide, slightly shorter than third coxa. Petiole dorsally smooth, latero-ventrally costate. Third abdominal tergum as long as fourth tergum in dorsal view. Fifth and sixth abdominal terga not visible from dorsal view.

Male. Same as female, except for longer antenna relative to body, with second to fourth flagellomeres dorsolaterally expanded and placodeal sensilla starting at F1; male antennal formula: 8(2.5), 3(2), 10(2.5), 9(2.5), 9(2.5), 9(2), 8(2), 8(2), $8(2), 8(2), 7.5(2), 7(2), 7(2), 9.5(2)$. POL:OOL:LOL ratio is 5:4:2; ocelli diameter 2 .

Type Material. Holotype 9 deposited in IAvH with the following labels: "Colombia, Cauca, PNN Munchique, Sector La Romelia, $2^{\circ} 38^{\prime} \mathrm{N} 76^{\circ} 54^{\prime} \mathrm{W}, 2640 \mathrm{~m}$, Malaise, 27.VII9.VIII.2004: H. Pino leg." (white label); "Holotype $ᄋ$ of A. timidus desig. Mata-Casanova" (red label). Paratypes (4 $q$ \& 2〕): "1 9 , Colombia, Magdalena, PNN Sierra Nevada de Santa Marta, El Ramo, $10^{\circ} 48^{\prime} \mathrm{N} 73^{\circ} 39^{\prime} \mathrm{W}, 2500 \mathrm{~m}$, Malaise, 29.I.15.II.2001: J. Cantillo leg" (deposited in IAvH); "1우, Colombia, Boyacá, SFF Iguaque, Cabaña Chaina, $5^{\circ} 25^{\prime} \mathrm{N}$ $73^{\circ} 27^{\prime} \mathrm{W}, 2600 \mathrm{~m}$, Malaise, 30.IV-17.V.2001: P. Reina leg" (deposited in IAvH); "1ㅇ, Colombia, PNN Cueva de los Guácharos, Alto el Mirador, $1^{\circ} 38^{\prime} \mathrm{N} 76^{\circ} 6^{\prime} \mathrm{W}, 1980 \mathrm{~m}$, Malaise, 2-5.XII.2001: D. Campos leg" (deposited in UB); " $10^{\top}$, Colombia, Valle del Cauca, Farallones de Cali, Cgto. La Meseta, 3 $34^{\prime} \mathrm{N} 76^{\circ} 40^{\prime} \mathrm{W}, 2080 \mathrm{~m}$, Malaise, 10-25.IX.2003: S.

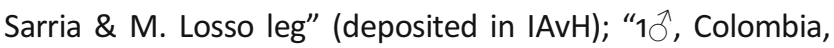
Valle del Cauca, Farallones de Cali, Cgto. La Meseta, $3^{\circ} 34^{\prime} \mathrm{N}$ 76 40'W, 2080 m, Malaise, 24.IX-9.X.2003: S. Sarria \& M. Losso leg" (deposited in UB); " $1+$, Colombia, Cauca, PNN Munchique, Sector La Romelia, $2^{\circ} 38^{\prime} \mathrm{N} 76^{\circ} 54^{\prime} \mathrm{W}, 2640 \mathrm{~m}$, Malaise, 27.VII-9.VIII.2004: H. Pino leg" (deposited in UB).

Derivatio Nominis. The specific name makes reference to the short scutellar spine and the smooth mesoscutum, which is in contrast with the elongated spine and areolate sculpture of mesoscutum that we can see in most species of the genus.

Biology. Unknown.

Distribution. Neotropical. Only collected from Colombia.

\section{Acanthaegilips truncatus Sp.N. Mata-Casanova \& Pujade-Villar}

Diagnosis. Species very close to $A$. exiguus Ros-Farré \& Pujade-Villar, 2003 and A. huggerti Sporrong \& Ros-Farré, 2013, to which it shares an open radial cell, presence of post-ocular furrow and absence of foveal carinae in scutellar foveae. However, it can be easily distinguished from these species by having a truncated scutellum, shorter than mesoscutum, a character only shared with $A$. timidus sp. $\mathrm{n}$. (scutellum longer than mesoscutum in the other described Acanthaegilips species).

Description. (Female).

Length. Body 2.4-2.6 mm. Wing 2.4-2.8 mm. Antenna 2.3$2.4 \mathrm{~mm}$.

Colour. Head, mesosoma and metasoma black. Antennae yellowish brown, scapus and pedicel darker. Mandibles yellowish brown with darker teeth. Legs yellowish brown, dark brown coxae. Wing veins dark yellowish.

Head. Head glabrous; 1.2 times wider than high in anterior view, 1.9 times wider than long in dorsal view. Malar furrow apparent and curved, connected with post-ocular furrow (Fig 2g). Genal carina absent, occipital carina strong. Malar space times 0.6 times of compound eye height. Transfacial line as long as compound eye height. Diameter of toruli bigger than intertoruli and ocular-torular distance. Compound eyes glabrous. POL:OOL:LOL ratio is 6:5.5:2.5; ocelli diameter 2 .

Antennae. Flagellomeres cylindrical, glabrous. Female antennal formula: 11(3.5), 3.5(2), 12(2), 9(2), 8(2), 7.5(2), 7(2.5), $6(2.5), 6(3), 5(3), 5(3), 5(3), 9(3)$. Placodeal sensilla starting at F2.

Mesosoma. Lateral pronotal carinae not dorsomedially projected to form raised tooth (Fig $2 \mathrm{~d}$ ). Pronotal plate rugose, with a few scattered hairs near dorsolateral margins. Pronotum alutaceous and pubescent, lateral surface with areolate sculpture, stronger in posterior pronotum. Mesoscutum with areolate sculpture (Fig 1b), 1.2 times wider than long in dorsal view. Median mesoscutal impression short, less than $1 / 4$ of mesoscutum total length. Notauli complete, comprised by cells (Fig 1b). Hair line on the anterior and lateral margins of the scutum absent. Parapsidal signum present and strong. Scutellum in dorsal view 0.7 times of mesoscutum total length in dorsal view. Scutellar foveae smooth with few irregular sculpture near its posterior margin; absence of internal longitudinal carinae (Fig 1b). Laterals pit of scutellar foveae present. Scutellar spine short, truncated, about $1 / 3$ of scutellar length. Scutellar disc in lateral view gradually descending towards terminus of spine. Mesopleural impression narrow and straight, without traces of any internal carinae (Fig 2d). Mesopleural triangle smooth and sparsely pubescent. Propodeum coriaceous and areolate, presence of an irregular median carina.

Wings. Pubescent. Radial cell of forewing open, 3.3 times longer than wide. R1 complete. Marginal pubescence of wing denser at apical third. 
Metasoma. Petiole as long as wide, shorter than third coxa. Petiole dorsally smooth, latero-ventrally costate. Third abdominal tergum as long as fourth tergum in dorsal view. Fifth and sixth abdominal terga not visible from dorsal view.

Male. Same as female, except for longer antenna relative to body, with second to fourth flagellomeres dorsolaterally expanded and placodeal sensilla starting at F1; male antennal formula: 8(3), 3(2.5), 7.5(2), 7.5(2), 8(2), 8(2), 7(2), 7(2), 7(2), $6(2), 6(2), 6(2), 6(2), 8(2)$. POL/OOL/LOL ratio is 6:5:3; ocelli diameter 2 .

Type Material. Holotype 9 deposited in IAvH with the following labels: "Colombia, Cauca, PNN Munchique, Sector La Romelia, $2^{\circ} 38^{\prime} \mathrm{N} 75^{\circ} 54^{\prime} \mathrm{W}, 2640 \mathrm{~m}$, Malaise, 24.V-9.VI.2004: E. Fino leg" (white label); "Holotype $q$ of $A$. truncatus desig. Mata-Casanova" (red label). Paratypes (1ठ& 19 ): "1우, Colombia, Boyacá, SFF Iguaque, Cabaña Mamarramos, $5^{\circ} 25^{\prime}$ N 7327'W, 2855 m, Malaise, 19.IV-6.V.2000: P. Reina leg" (deposited in $\mathrm{IAvH}$ ); "1 $\widehat{\jmath}$, Colombia, Boyacá, SFF Iguaque, Qda. Carrizal, $5^{\circ} 25^{\prime} \mathrm{N} 73^{\circ} 27^{\prime} \mathrm{W}, 3350 \mathrm{~m}$, Malaise, 123.IX.2000: P. Reina leg" (deposited in UB).

Derivatio Nominis. The specific name makes reference to the short and truncate scutellar spine.

Biology. Unknown.

Distribution. Neotropical. Only collected from Colombia.

\section{Discussion}

The four newly discovered species expand the morphological characters associated with Acanthaegilips. Acanthaegilips truncatus sp. $\mathrm{n}$. has a strong areolate mesoscutum, like most of Acanthaegilips species (Ros-Farré et al 2003, Mata-Casanova \& Pujade-Villar 2013a, 2013b); however, the scutellar spine is truncate and shorter than the total length of the mesoscutum (Figs $2 \mathrm{C}$ and 4e), a feature that casts it apart from the rest of areolate Acanthaegilips species. The other three species, $A$. timidus n. sp., $A$. boyacensis n. sp. and $A$. curvis n. sp., have a smooth mesoscutum with incomplete notauli ((Fig 1a-c); this feature has never been previously seen in Acanthaegilips: the previously described species of the genus had either an areolate mesoscutum or carinate one (Pujade-Villar et al 2009a) and always presented complete notauli.

The three species with smooth mesoscutum can be divided into two categories according to the shape and length of the scutellar spine. While $A$. timidus $\mathrm{n}$. sp. has a short scutellar spine (Fig 1a) (like A. truncatus n. sp.), A. boyacensis n. sp. and A. curvis $\mathrm{n}$. sp. have a longer scutellar spine like in the rest of the Acanthaegilips species (Fig $1 \mathrm{~b}, \mathrm{c}$ ). This characteristic is not enough to consider as theme to be of different species; it is not strange to see sexual dimorphism regarding the radial cell in Acanthaegilips (Ros-Farré et al 2000) and taking into account that the two specimen studies belong to different sexes, it was difficult to assess if they are of different species. However, there are also differences regarding the malar area: while $A$. boyecensis $\mathrm{n}$. sp. presents a slightly curved malar furrow and lacks post-ocular furrow, $A$. curvis n. sp. presents both malar and post-ocular furrow, the first being strongly curved and connected to the former. This feature is not due to sexual dimorphism and has taxonomic importance, hence separating the specimens in two different species.

Considering that the last species key for Acanthaegilips is the one found in Ros-Farré et al (2003), we thought that an updated key of the genus should be included, taking into account the species described since then and the interesting morphological features they present.

The bulk of known Acanthaegilips species diversity is located in Venezuela and Colombia-most probably due to a collection bias. The description of these four new species increases the Colombian Acanthaegilips diversity to 11 species, surpassing Venezuela as the country with the most species of this genus. Despite being only found in Colombia, it is very plausible for these species to have a larger distribution area. More research should be done in order to confirm this statement and unveil more aspects about their biology that remain unknown for now.

Acknowledgments Thanks are due to Claudia Medina (IAvH) for loaning of the undetermined materials in which this study is based. This study has been funded by project CGL2011-22889 of the Science and Innovation Ministry of Spain.

Nomenclature ZooBank registration can be found for A. boyacensis: http://zoobank.org/urn:Isid:zoobank.org:act:00528B9153D7-4D4F-9EE4-901BF5B1E218;

A. curvis: http://zoobank.org/urn:Isid:zoobank.org:act:F95792F9-3CoB41C4-A62D-F298B439FBFE;

A. timidus: http://zoobank.org/urn:Isid:zoobank.org:act:6ADA87D4BDBA-4C5D-BB37-17A7FB9A9C3E;

A. truncatus: http://zoobank.org/urn:Isid:zoobank.org:act:88C5E5E1453F-4FD2-8706-ADCE4057E5D6.

\section{References}

Cave RD, Miller GL (1987) Notes on Anacharis melanoneura (Hymenoptera: Figitidae) and Charitopes mellicornis (hymenoptera: Ichneumonidae) parasitizing Micromus posticus (Neuroptera: Hemerobiidae). Entomological News 98:211-216

Díaz NB (1979) Himenópteros Neotropicales parasitoides de Neurópteros I, Cynipoidea. Revista de la Sociedad Entomológica Argentina 38(1-4):21-28

Fergusson NDM (1985) British species of the parasitic cynipid wasp genus Aegilips (Hymenoptera: Cynipoidea, Anacharitinae). J Nat Hist 19: 811-818

Kierych E (1984) Notes on the genus Prosynapsis D. T. et Kieff. (Synapsis Först) with a list of Anacharis Dalm. Species occurring in Poland 
(Hymenoptera, Cynipoidea, Anacharitidae). Annales Zoologici 37(11): 335-339

Mata-Casanova N, Pujade-Villar J (2013a) Acanthaegilopsis malagasy gen. n. and sp. n. Of Anacharitinae (Hymenoptera: Cynipoidea: Figitidae) from Madagascar and the Comoros. African Entomology 21(1):161-164

Mata-Casanova N, Pujade-Villar J (2013b) Nuevas aportaciones al conocimiento de Acanthaegilips en Colombia (Hymenoptera: Figitidae: Anacharitinae). Revista colombiana de Entomología 39(1):71-75

Mata-Casanova N, Selfa J, Arcaya E, Sosa F, Tormos J, Pujade-Villar J (2014) First host record for Acanthaegilips (Hymenoptera: Figitidae: Anacharitinae) and description of a new species from Venezuela. Fla Entomol 97(2):461-464

Miller GL, Lambdin PL (1985) Observations on Anacharis melanoneura (Hymenoptera: Figitidae), a parasite of Hemerobius stigma (Neuroptera: Hemerobiidae). Entomological News 96:93-97

New TR (1979) An Australian species of Xyalaspis Hartig (Hymenoptera: Figitidae). J Aust Entomol Soc 18:177-180

Paretas-Martínez J, Restrepo-Ortiz CX, Buffington M, Pujade-Villar J (2011) Systematics of Australian Thrasorinae (Hymenoptera, Cynipoidea, Figitidae) with descriptions of Mikeiinae, new subfamily, two new genera, and three new species. Zookeys 108:21-48
Pujade-Villar J, Restrepo-Ortiz CX, García JL, Ros-Farré P (2009a) Redescripción de Acanthaegilips Ashmead 1897 y descripción de dos nuevas especies (Figitidae: Anacharitinae). Dugesiana 16(2):57-65

Pujade-Villar J, Restrepo-Ortiz CX, Ros-Farré P, García JL (2009b) Acanthaegilips Ashmead, 1897 (Cynipoidea, Figitidae: Anacharitinae) de Venezuela. Entomotropica 24(1):23-30

Restrepo-Ortiz CX, Ros-Farré P, Díaz NB, García JL, Pujade-Villar J (2010) Nuevos aportes al conocimiento del género Acanthaegilips (Hymenoptera: Figitidae). Revista de la Sociedad Entomológica Argentina 69(1-2):09-16

Richards OW (1977) Hymenoptera. . In: Handbooks for the identification of British insects. 2nd Edn. 6(1): 1-100. British Museum and Royal Entomological Society, London

Ronquist F (1995) Phylogeny and early evolution of the Cynipoidea (Hymenoptera). Syst Entomol 20:309-335

Ros-Farré P, Ronquist F, Pujade-Villar J (2000) Redescription of Acanthaegilips Ashmead, 1897, with characterization of the Anacharitinae and Aspiceratinae (Hymenoptera: Cynipoidea: Figitidae). Zool J Linnean Soc 129:467-488

Ros-Farré P, Sporrong M, Ronquist F, Pujade-Villar J (2003) Revision of the Neotropical genus Acanthaegilips (Hym., Cynipoidea, Figtidae). Papéis Avulsos de Zoologia 43(2):11-30 